\title{
ADAPTIVE MARKETS HYPOTHESIS: EMPIRICAL EVIDENCE FROM MONTENEGRO EQUITY MARKET
}

\author{
Saša Popovića , Ana Mugoša ${ }^{b}$, Andrija Đurovićc

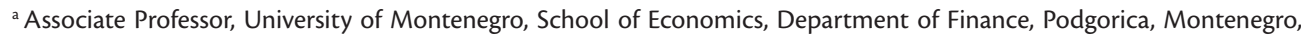 \\ sasap@ac.me \\ ${ }^{\mathrm{b}}$ Teaching Asistant, University of Montenegro, School of Economics, Department of Finance, Podgorica, Montenegro, \\ ana.mugosa@ac.me \\ 'Assitent for Analysis and Reporting, Hypo Alpe Adria Bank, Podgorica, Montenegro, djandrija@gmail.com
}

\section{ARTICLE INFO \\ Article data: \\ - Received: 20 February 2012 \\ - Accepted: 9 October 2012}

JEL classification: C12, C14, G10, G14

Keywords:

- Adaptive Markets Hypothesis

- Weak-form of Efficient Market

Hypothesis

- Rolling analysis

- Autocorrelation coefficient

- Runs test

- Montenegro

\section{ABSTRACT}

In this paper we examined adaptive markets hypothesis $(\mathrm{AMH})$ using three factors we assumed that affect weak-form of market efficiency: observation period, time horizon represented by rolling window sizes and data aggregation level. We have analyzed market value weighted index MONEX20, which is proxy from Montenegro equity market, over 20042011 period. Rolling window analysis with fixed parameter in each window is employed to measure the persistence of deviations from a random walk hypothesis (RWH) over time. Actually, using rolling sample approach we checked whether short-range linear dependence is varying over time. This method was applied on the first order serial autocorrelation coefficients (AC1), as well as on runs test, since evidence on non-normality properties of MONEX20 suggests using non-parametric test. The evidence was found that all three factors impact degree of weakform Montenegro equity market efficiency which has serious consequences on profit opportunities over time on this market.

Reference to this paper should be made as follows: Popović. S, Mugoša. A, Đurović. A 2013. Adaptive Markets Hypothesis: Empirical Evidence from Montenegro Equity Market, Ekonomska istraživanja Economic Research 26(3): 31-46 


\section{INTRODUCTION}

The concept of market efficiency is the core paradigm of finance. This term is used to describe return generation process which has important implication on financial models based on rational expectations. Mobarek and Keasey (2000) recall that the weak-form of efficient market hypothesis (EMH) tests measure whether past series of share prices or returns can be used to successfully predict future share prices or returns. The major empirical investigation of the above tests measures the statistical dependence between price changes. If no dependence is found, meaning price changes randomly, then this provides evidence in support of the weak-form of $\mathrm{EMH}$, which implies that no profitable investment trading strategy can be derived based on past prices. While, if dependence is found, which means price do not change randomly, the basis of profitable investment rule is created and the assumption of the weak-form of EMH is violated. However, profitability of a trading rule depends largely on the operating costs (such as brokerage cost, interest cost, settlement cost) and on opportunity to make transactions at the exact prices quoted in the market.

The literature on capital markets efficiency is very large, and Eugen Fama (1991) did a great effort to make review of most interesting ideas and approaches to $\mathrm{EMH}$. Also, very useful overview of the different concepts of market efficiency and their anomalies was offered by Dimson and Mussavian (2000) starting with the Bacheliers doctoral dissertation submitted in 1900, when concept of market efficiency had been anticipated for the first time. The EMH theory has been extended and analyzed in many other directions (LeRoy, 1973; Lucas, 1978) and from different regional and national market perspectives (Worthington and Higgs, 2004).

Lim and Brooks classify the weak-form EMH literature based on the research framework adopted, namely 1) full sample (fixed parameter); 2) sub-samples (non-overlapping, fixed parameter); 3) full sample (time-varying parameter) and 4) rolling estimation windows (overlapping but fixed parameter in each window).

Although the idea that market prices incorporate all information rationally and instantaneously is over 40 years old, various researches notice that the emerging discipline of behavioral economics and finance has challenged this hypothesis, arguing that markets are not rational, but are driven by fear and greed instead. In his article Lo (2004) proposed a new framework that reconciles market efficiency with behavioral alternatives by applying the principles of evolutionary approach to economic interactions. The proposed reconciliation, Lo named the "Adaptive Markets Hypothesis" (AMH). As Lim and Brooks (2011) stated in their literature review the AMH implies more complex market dynamics, such as cycles, trends, bubbles, crashes, manias and other phenomena that occur in the financial markets. They also briefly described Lo's research $(2004,2005)$ which offers a concrete example by computing the rolling first-order autocorrelation for monthly returns of the Standard \& Poor's (S\&P) Composite Index from January 1871 to April 2003. Lim and Brooks emphasize that "his graphical plot reveals that the degree of efficiency, measured by the first order autocorrelation coefficient, varies through time in a cyclical fashion with the surprising result that the US market is more efficient in the 1950s than in the early 1990s."

The possibility that market efficiency does evolve over time is also described by Self and Mathur (2006): "The true underlying market structure of asset prices is still unknown. However, we do know that, for a period of time, it behaves according to the classical definition of an efficient market; then, for a period, it behaves in such a way that researchers are able to systematically find anomalies to the behavior expected of an efficient market."

In their paper Todea at al. (2009) investigated the profitability of the moving average 
strategy on six Asian capital markets considering the episodic character of linear and/or non linear dependencies over 1997-2008. The main conclusion is that profitability of moving average strategies is not constant in time, but it is episodic showing when sub-periods of linear and nonlinear correlation appear.

Neely et al. (2009) examined the intertemporal stability over time of the excess returns earned by several broad classes of technical trading rules in the foreign exchange market. Their findings where consistent with adaptive markets hypothesis, as they showed that both institutional and behavioral factors influence investment strategies and opportunities on foreign exchange market. Research from various authors like Brock et al. (1992) and Sullivan at al. (1997) have also found evidence that particular classes of technical trading rules enable the possibility of earning abnormal profit in the stock market.

The effect of changing market conditions on DJIA return predictability, which is consistent with adaptive markets hypothesis, was found in study by Kim et al. (2011). As they concluded, return predictability is associated with stock market volatility and economic fundamentals. Additionally, there are various studies which point out the importance of the behavioral finance and discuss that investor's behavior like overreaction and overconfidence is irrational, but still highly predictable (DeBondt and Thaler, 1985; Barber and Ordean, 2001)

Apart from the main finding of time-varying weak-form efficiency in stock markets, the rolling window approach allows previous studies to gain additional insight. Despite the qualitative nature of $\mathrm{AMH}$, it offers a number of concrete implications for the practice of investment management.

Next table shows an overview of results of the main papers related to Adaptive Market Hypothesis testing. 

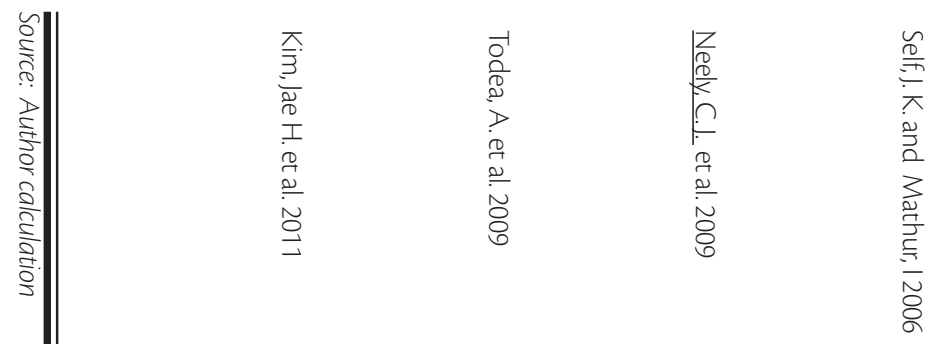

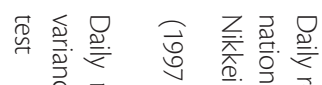

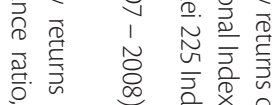

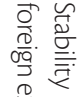

ํ.

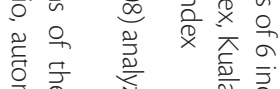

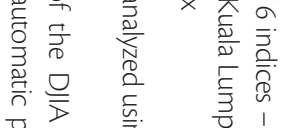

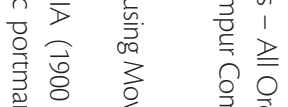

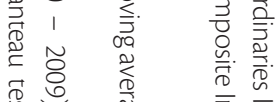

品 व

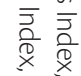

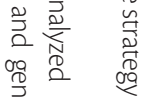

舍.

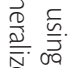

矛施

足

芩

竞高

$\stackrel{\text { Dे }}{\cap}$.

气े 耑

爱

产

产. 胥

永

\

竞

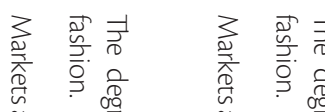

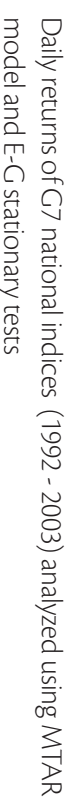

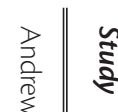

$\stackrel{\oiiint}{\frac{1}{2}}$

$\sum$

号

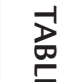

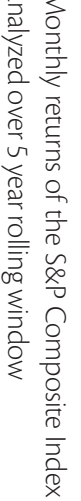

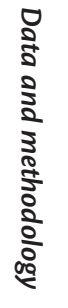

20

⿳亠े了.

节

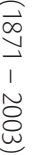

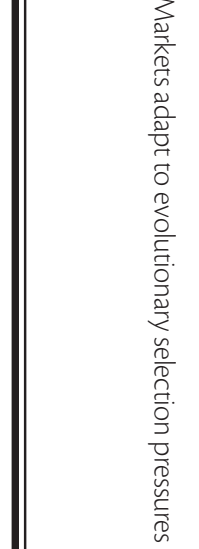

o9

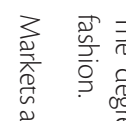

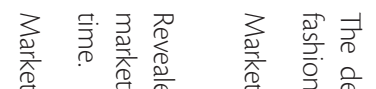

突

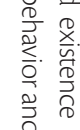

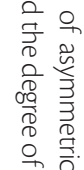

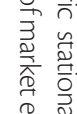

品

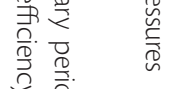

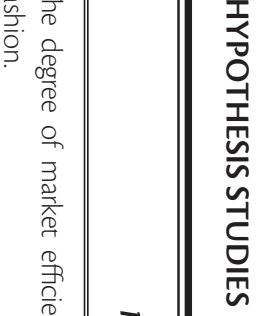


It is important to notice that the Adaptive Market Hypothesis was not analyzed in too many studies. Additionally, the authors of above compared studies analyzed whether market efficiency changes during the observation period which resulted with conclusion that market efficiency changes over time. We did get to the same results which proved that market efficiency changes over time, and contributed to these types of studies examining two additional factors: time horizon and data aggregation level.

\section{DATA DESCRIPTION}

In this study we analyze daily data of MONEX20, market value-weighted index which is proxy for Montenegro equity market. The data is analyzed over period of eight years, starting from January $13^{\text {th }} 2004$ to December $31^{\text {st }} 2011$. This period covers all available data of MONEX20. In order to obtain time series of continuously compounded returns, we transformed daily data of MONEX20 according to the formula

$$
r_{t}=\log \left(\frac{p_{t}}{p_{t-1}}\right) 100
$$

where $p_{t}$ and $p_{t-1}$ represent the stock index value at time $t$ and $t-1$, respectively. Weekly data is obtained by averaging daily returns. We examined three factors we assumed to influence degree of weak-form of market efficiency: observation period (P, P1, and P2), time horizon (rolling window sizes), and aggregation level (daily and weekly returns). The higher levels of data aggregation were not considered due to relatively short length of available MONEX20 data. Observation period $P$ was divided in two sub-periods: P1, ranging from 2004 to 2008 and P2, from 2009 to 2011. Subperiod $\mathrm{P} 1$ reflects rapid development of Montenegro capital market as a consequence of massvoucher privatization process which is characterized by euphoria, while sub-period $\mathrm{P} 2$ reflects stock market collapse as a consequence of global financial crisis and vulnerability of small emerging market. In order to test the structural stability of original data series of daily returns, we applied the t-test, which showed statistically significant difference between means for two sub-periods (for P1 (2004-2008) mean value is 0.001701 and for P2 (2009-2011) mean value is -0.0000947 ), with a p-value of 0.02556 .

We have employed rolling window method, in order to assess the stability of first order autocorrelation coefficient and stability of the results of runs test. First order autocorrelation coefficient is employed because it was found that this coefficient was statistically significant for daily and weekly aggregation level. Since evidence on non-normality properties of MONEX20 suggests using non-parametric test, the runs test was used. To make possible comparison between two aggregation levels we have chosen different rolling window sizes in order to cover approximately one year period for both aggregation levels.

Table 2 presents summary of descriptive statistics of daily and weekly returns for total observation period ( $P$ ) and two sub-periods (P1 and P2). Sample means, standard deviations, ranges, skewness, kurtosis, Jarque-Bera statistics, Augmented Dickey-Fuller statistics and p-values have been reported. The mean of continuously compounded returns for MONEX20 ranges from $-0.097(\mathrm{~min})$ to $0.113(\mathrm{max})$, and $-0.051(\mathrm{~min})$ to $0.066(\mathrm{max})$ for daily and weekly data, respectively. Reported skewness and kurtosis indicate strong non-normal distributional properties for both aggregation levels and sub-periods. Jarque-Bera statistics and corresponding $p$-values justify non-normality properties of the series. Also, Augmented Dickey-Fuller (ADF) statistics and its corresponding $\mathrm{p}$-values test null hypothesis of unit root (non-stationary) against the alternative of no unit root (stationary) and we accepted alternative hypothesis that MONEX20 is stationary time series for both aggregation levels and both sub-periods. 


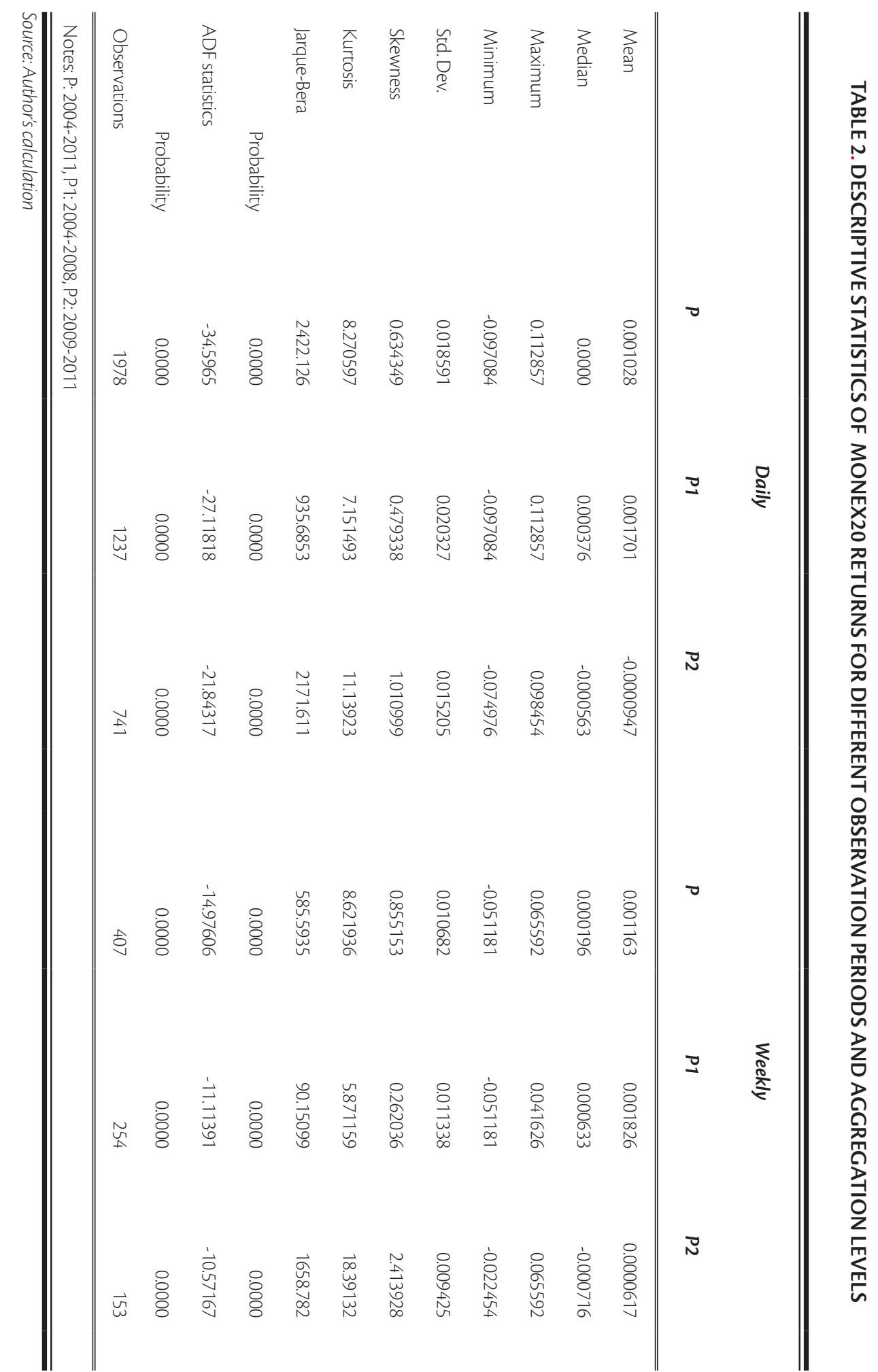


Figure 1. Returns on MONEX20 for different aggregation levels
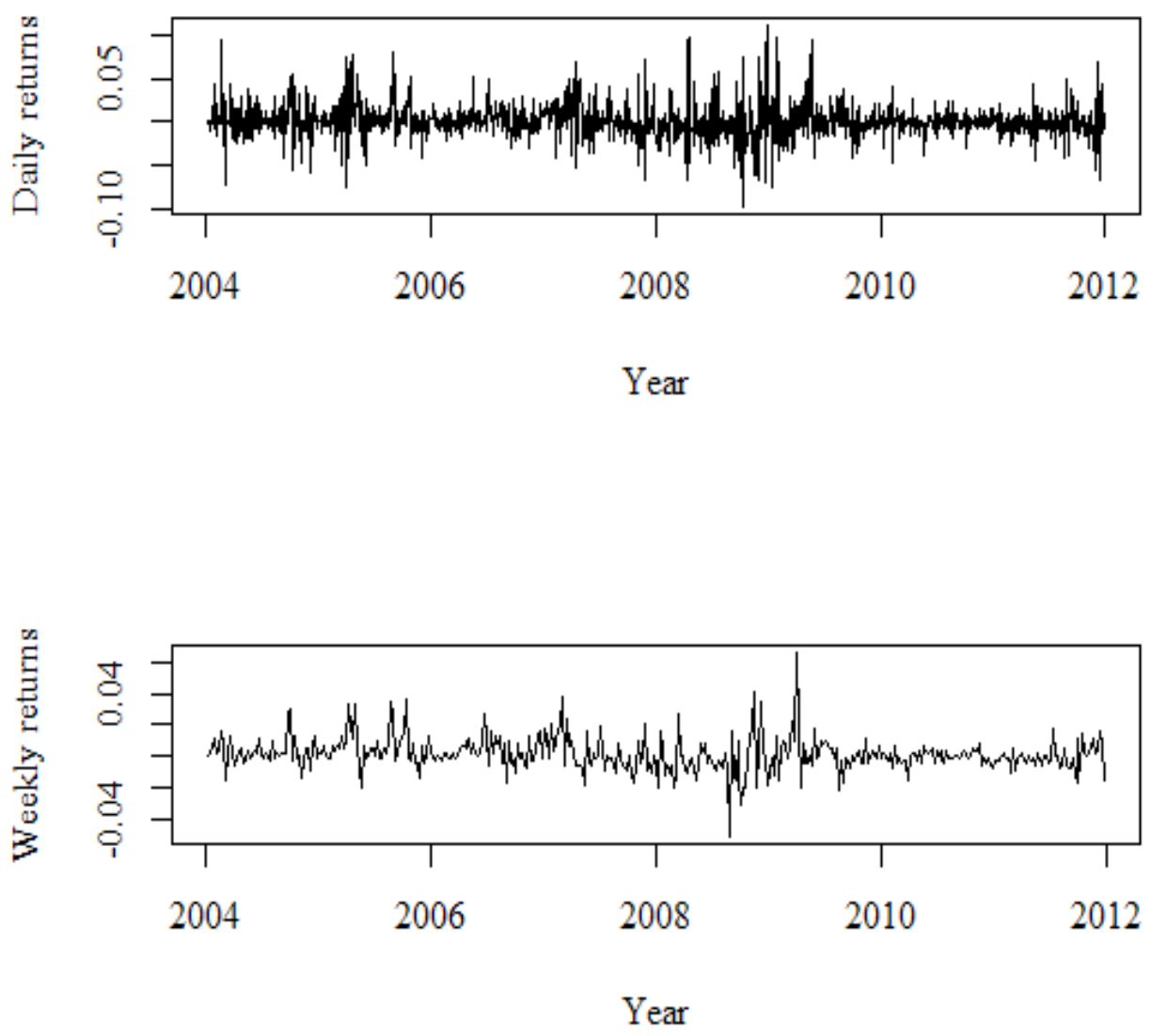

FIGURE 1 DISPLAYS MONEX20 RETURNS. 


\section{METHODOLOGY}

Consider the following random walk process:

$$
\mathrm{r}_{\mathrm{t}}=\mathrm{r}_{\mathrm{t}-1}+\varepsilon_{\mathrm{t}}
$$

where $r_{t}$ and $r_{t-1}$ represent the returns on MONEX20 index at time $t$ and $t-1$, respectively, and $\varepsilon_{t}$ is a random disturbance term satisfying $\mathrm{E}\left(\varepsilon_{t}\right)=0$ and $\mathrm{E}\left(\varepsilon_{t}, \varepsilon_{t-\mathrm{g}}\right)=0, \mathrm{~g} \neq 0$, for all $t$. If return generation process follows model (2) we conclude that market is weak-form efficient. As Worthington and Higgs noted, the best predictor of future prices is the most current price, so, "in a market which complies with random walk, it is not possible to use information on past prices to predict the future prices" (Worthington and Higgs, 2004).

In order to analyze how observation period, time horizon (represented by rolling window sizes) and data aggregation level influence weak-form market efficiency we employed rolling window method to test stability of first order autocorrelation coefficient $(A C(1))$, as well as to test results of runs test.

First order autocorrelation coefficient is given by:

$$
A C(1)=\frac{\sum_{t=1}^{N-1}\left(r_{t}-\bar{r}_{1}\right)\left(r_{t+1}-\bar{r}_{2}\right)}{\left[\sum_{t=1}^{N-1}\left(r_{t}-\bar{r}_{1}\right)^{2}\right]^{1 / 2}\left[\sum_{t=2}^{N-1}\left(r_{t}-\bar{r}_{2}\right)^{2}\right]^{1 / 2}}
$$

where $\mathrm{N}$ is the number of observations, $\bar{r}_{1}$ is the mean of the first $\mathrm{N}-1$ observations and $\bar{r}_{2}$ is the mean of the last $\mathrm{N}-1$ observations. If absolute $\mathrm{AC}(1)$ significantly differs from zero its calculated value should be out of limits, where limits are given by:

$$
\pm z_{\alpha / 2} \frac{1}{\sqrt{N}}
$$

Runs test is non-parametric test which is traditionally used in random walk model and ignores properties of distribution. This test ignores the absolute value in time series and takes into consideration only the price changes of the same sign, which are called runs (Popović, 2000). Actual number of runs is being compared with the expected number of runs, obtained by applying the following formula

$$
\mu(R)=\frac{2 n_{1} n_{2}}{n_{1}+n_{2}}+1
$$

where $\mu(R)$ is expected number of runs, and $n_{1}, n_{2}$ are sums of positive and negative runs, respectively. 
The standard error of the expected number of runs is calculated as follows:

$$
\sigma(R)=\sqrt{\frac{2 n_{1} n_{2}\left(2 n_{1} n_{2}-n_{1}-n_{2}\right)}{\left(n_{1}+n_{2}\right)^{2}\left(n_{1}+n_{2}-1\right)}+1}
$$

Expected number of runs is compared with the actual number of runs $(R)$, i.e. with number of sequences of the returns with the same signs (+ or -). The difference between actual number of runs and expected number of runs can be expressed by a standardized-normalized value of $Z$, as follows:

$$
Z=\frac{R-\mu(R)}{\sigma(R)}
$$

The null hypothesis for the runs test is that the observed returns are randomly distributed. The null hypothesis is rejected if the calculated number of runs falls outside the $95 \%$ confidence interval: $\mu(R)-1.96 \sigma(R) \leq R \leq \mu(R)+1.96 \sigma(R)$, and is accepted if the value lies in between \pm 1.96 . The Z-value is tested at $5 \%$ significance level, that is, the null hypothesis can not be rejected with $95 \%$ confidence level. In other words there is a probability of rejecting a null hypothesis when it is true 5 out 100 times.

The percentage of $A C(1)$ which are out of limits, as well as percentage of runs test rejecting null hypothesis at $5 \%$ significance level were calculated by employing rolling analysis for different window sizes. The main idea of the rolling window approach in this research is to check whether short-range linear dependence is varying over time. This approach is of use to test whether stock market efficiency is changing over time.

\section{EMIPIRICAL RESULTS}

Table 3 displays different rolling window sizes according to aggregation levels we examined. There is no standard rule by which the right size of the rolling window could be defined. When applying this analysis, the size of rolling window is related to the length of time series. Over period of eight years, starting from January $13^{\text {th }} 2004$ to December $31^{\text {st }} 2011$, which encompasses all available data on Montenegro Stock Exchange, we analyzed two aggregation levels - daily and weekly. Additionally, we had to trade-off between sufficient number of windows and windows length. In order to obtain statistically valid results, 50 days were the minimal rolling window size for each aggregation level and periods analyzed. We were guided by the same principle, when choosing applied windows sizes.

\begin{tabular}{|c|c|c|c|c|}
\hline \multicolumn{5}{|c|}{ Rolling window sizes $(n)$} \\
\hline Daily & 50 & 100 & 200 & 300 \\
\hline Weekly & 10 & 20 & 40 & 60 \\
\hline
\end{tabular}

TABLE 3. ROLLING WINDOW SIZE ACCORDING TO AGGREGATION LEVEL

Source: Author's calculation 
Percentages of out of limits $\mathrm{AC}(1)$ for different rolling window sizes, aggregation levels and observation periods (P, P1 and P2) are shown in Table 4. Higer percentage indicates lower degree of weak-form market efficiency, while lower percentage implies higer degree of weak-form market efficiency.

\section{TABLE 4. PERCENTAGE OF OUT OF LIMITS AC(1) FOR DIFFERENT ROLLING WINDOW SIZES AND AGGREGATION LEVELS}

\begin{tabular}{|c|c|c|c|c|c|c|c|c|}
\hline & \multicolumn{4}{|c|}{ Daily } & \multicolumn{4}{|c|}{ Weekly } \\
\hline & $n=50$ & $n=100$ & $n=200$ & $n=300$ & $n=10$ & $n=20$ & $n=40$ & $n=60$ \\
\hline Out of limits $P$ & 54.17 & 71.63 & 64.59 & 67.42 & 0.98 & 3.02 & 13.00 & 20.17 \\
\hline Out of limits P1 & 58.62 & 80.05 & 77.86 & 75.55 & 0.78 & 3.19 & 20.33 & 31.17 \\
\hline Out of limits P2 & 46.65 & 57.16 & 41.03 & 52.45 & 1.32 & 2.74 & 0.00 & 0.00 \\
\hline Notes: & 11 & 4 & . 2000 & & & & & \\
\hline
\end{tabular}

Source: Author's calculation

\section{Observation period}

The results indicate that sub-period P2 is the same or more efficient than P1 for both aggregation levels and for all rolling window sizes employed. By increasing rolling window size towards longer time horizon, the difference of market efficiency degree between two sub-periods P1 and P2 becomes more evident for both aggregation levels. The whole observation period is characterized by cyclical changes of market efficiency on daily level, while by increasing time horizon on weekly level, the market efficiency decreases.

\section{Data aggregation level}

From the data aggregation perspective, the higher level of aggregation increases degree of market efficiency, no matter which period of observation and time horizon is considered.

\section{Time horizon}

If time horizon becomes broader by widening rolling window size, degree of market efficiency decreases over total observation period $(P)$ and sub-period $P 1$, on weekly aggregation level. Sub-period $\mathrm{P} 2$ has shown specific pattern of efficiency, comparing to $\mathrm{P}$ and $\mathrm{P} 1$ : by increasing time horizon form $n=10$ to $n=20$, the degree of market efficiency decreases (from $1.32 \%$ to $2.74 \%$ out of limits), while further increase of rolling window size leads to increase of market efficiency (from $2.74 \%$ to $0.00 \%$ out of limits). Considering daily data, as adaptive markets hypothesis suggests, degree of market efficiency is changing in a cyclical manner, for total as well as for both subperiods. Note that over total observation period cyclical changes result as follows: by increasing window size from 50 to 100 degree of market efficiency decreases (from $54.17 \%$ to $71.63 \%$ out of limits), than, by increasing from 100 to 200 degree of market efficiency increases (from $71.63 \%$ to 64.59 out of limits), and finally, by increasing from 200 to 300 degree of market efficiency again decreases (from $64.59 \%$ to $67.42 \%$ out of limits). 
Graphic presentation of daily and weekly $\mathrm{AC}(1)$ for different rolling window sizes are given by Figure 2 and Figure 3, respectively.

Figure 2. Daily AC(1) for different rolling window sizes
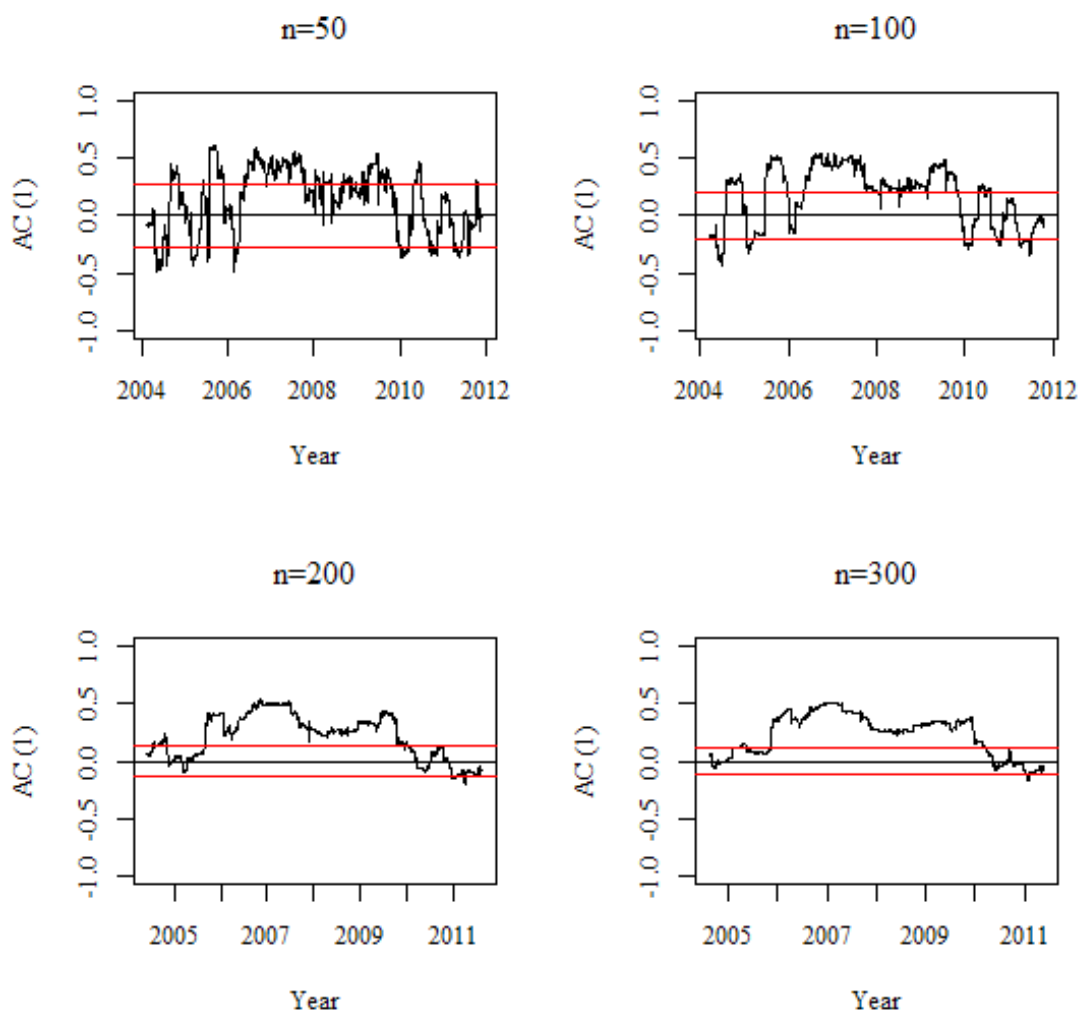

Source: Author's calculation 
Figure 3. Weekly $\mathrm{AC}(1)$ for different rolling window sizes
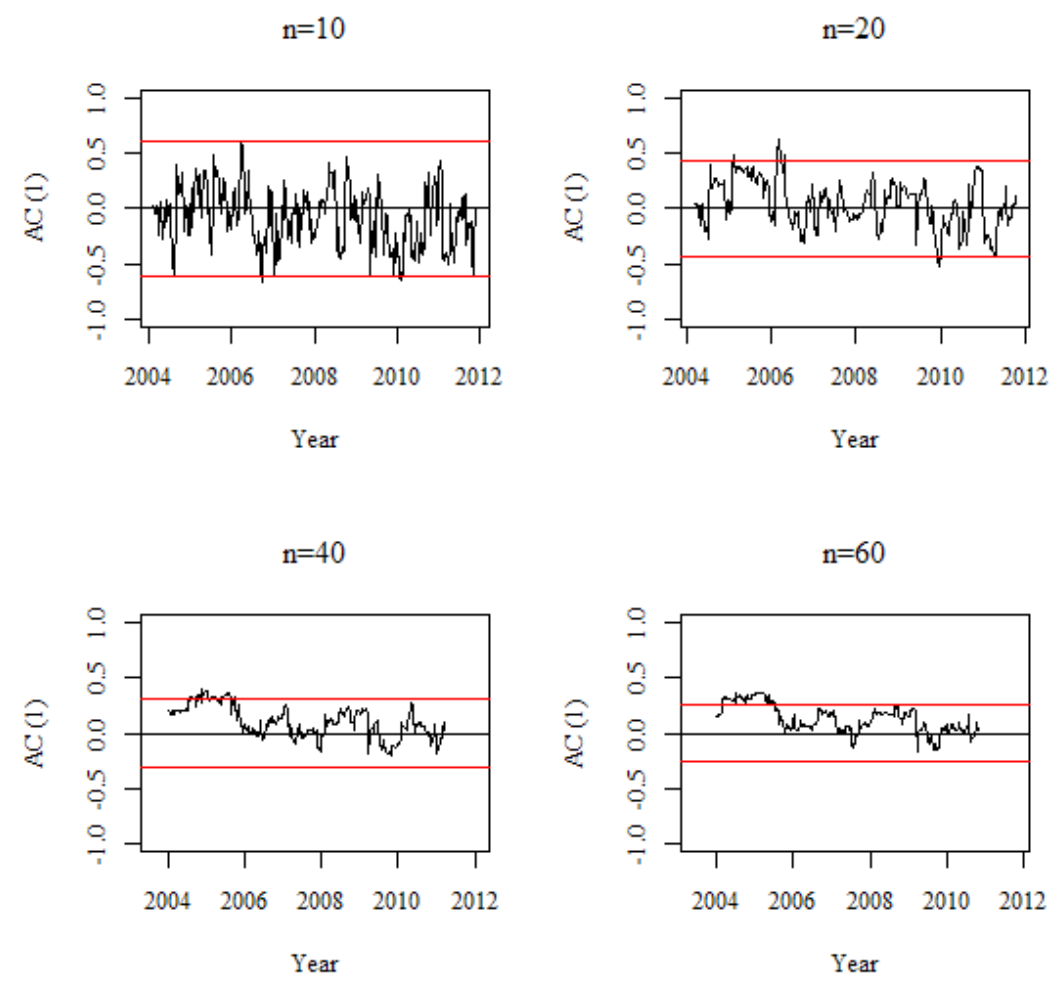

Source: Author's calculation

Table 5 shows the percentage of runs test that reject random walk hypothesis at $5 \%$ significance level for different rolling window sizes, aggregation levels and observation periods (P, P1 and P2).

\section{TABLE 5. PERCENTAGE OF THE RUNS TEST THAT REJECT RW HYPOTHESIS FOR DIFFERENT ROLLING WINDOW SIZES AND AGGREGATION LEVELS}

\begin{tabular}{|c|c|c|c|c|c|c|c|c|}
\hline & \multicolumn{4}{|c|}{ Daily } & \multicolumn{4}{|c|}{ Weekly } \\
\hline & $n=50$ & $n=100$ & $n=200$ & $n=300$ & $n=10$ & $n=20$ & $n=40$ & $n=60$ \\
\hline Out of limits P & 25.78 & 37.51 & 49.43 & 56.72 & 9.34 & 9.07 & 7.69 & 7.00 \\
\hline Out of limits P1 & 29.73 & 43.85 & 53.50 & 64.69 & 8.98 & 7.97 & 10.79 & 7.79 \\
\hline Out of limits P2 & 19.10 & 26.64 & 42.23 & 42.08 & 9.93 & 10.96 & 2.21 & 5.56 \\
\hline Notes: & 1. & 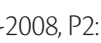 & $9-2011$ & & & & & \\
\hline
\end{tabular}

Source: Author's calculation

42 ADAPTIVE MARKETS HYPOTHESIS: EMPIRICAL EVIDENCE FROM MONTENEGRO EQUITY MARKET 


\section{Observation period}

According to the results obtained by runs test, market efficiency of sub-period P2 comparing to P1 depends on aggregation level as well as time horizon considered. On daily aggregation level, P2 is always more efficient comparing to P1, no matter which time horizon is considered. At weekly aggregation for $n=10$ in=20 degree of market efficiency in $\mathrm{P} 1$ is higher than in $\mathrm{P} 2$ (compare $8.98 \%$ to $9.93 \%$ out of limits for $n=10$ and $7.97 \%$ to $10.96 \%$ for $n=20$ ). The conclusion is quite opposite when taking into consideration $n=40 i n=60$ (compare $10.79 \%$ to $2.21 \%$ out of limits for $n=40$ and $7.97 \%$ to $5.56 \%$ for $n=60$ ). Opposite to $A C(1)$ test, the results of runs test have shown absence of cyclical changes in market efficiency over whole observation period on daily level. By increasing time horizon over total observation period the degree of market efficiency decreases on daily aggregation level, while increases on weekly level of aggregation.

\section{Data aggregation level}

The higher level of aggregation increases degree of market efficiency, no matter which time horizon and which period of observation is taken into consideration.

\section{Time horizon}

As we already explained, wider time horizon reflects lower degree of market efficiency on daily aggregation level over total observation period $P$, while on weekly aggregation level it reflects higher degree of efficiency. The same conclusion can be drown for both sub-periods on the basis of daily data, but at weekly data we found cyclical changes in both of them.

\section{CONCLUDING REMARKS}

This paper seeks evidence whether three factors: observation period, time horizon, and data aggregation level affects degree of efficiency of Montenegro equity market. We focused on examining degree of market efficiency over time and the main finding of this paper is that we proved adaptive markets hypothesis. General conclusion is that all three factors effects degree of efficiency of Montenegro equity market which has serious consequences on profit opportunities over time on this market. Employed tests have shown that influence of those factors is mutually dependant and interactive. In order to examine correlation between current and past returns of MONEX20, the rolling analysis was employed on $A C(1)$ and on $p$-value of runs test. The results of both tests proved time-varying market efficiency.

Our findings can be summarized as follows:

- Period of euphoria (P1) and period of recession (P2) have shown different degree of Montenegro equity market efficiency. Generally, over P1 period market was less efficient comparing P2. Note that over two sub-periods there are intervals with different degree of market efficiency which proves adaptive markets hypothesis and time varying character of market efficiency.

- From data aggregation perspective we conclude that increasing data aggregation level increases degree of market efficiency. This finding is highly intuitive because averaging daily data in order to get weekly, influence of factors that cause lower efficiency decreases.

- By widening time horizon (rolling window size), degree of market efficiency generally decreases and we found evidence that decrease has a cyclical pattern.

Both tests employed proved adaptive markets hypothesis, but using $\mathrm{AC}(1)$ cyclical changes were found on daily aggregation level, while, using runs test these changes were found 
on weekly aggregation level. The reason for this could lie in fact that we only used rolling window sizes which refers to period up to one year. That could be considered as short term, in which data is more volatile. Using such rolling window sizes was consequence of relatively short available MONEX20 time series.

\section{REFERENCES}

Barber, B. M. \& Odean, T. Boys will be boys: gender, overconfidence, and common stock investment. Quarterly Journal of Economics,116(1), (2001): 261-292.

Brock. W., Lakonishok, J., \& LeBaron, B. Simple Technical Trading Rules and the Stochastic Properties of Stock Returns. Journal of Finance, 47, (1992): 1731-1764.

DeBondt, W., \& Thaler, R. Does the stock market overreact?. Journal of Finance, 40, (1985): $793-$ 808.

Dimson, E. \& Musavian, M. Market Efficiency. The Current State of Business Disciplines, 3, (2000): 959-970.

Fama, E. F. Efficient Capital Markets: II. The Journal of Finance, 46 (5), (1991): 1575-1610.

Kim, J. H., Shamsuddin, A., \& Lim, Kian-Ping. Stock Return Predictability and the Adaptive Markets Hypothesis: Evidence from Century-Long U.S. data. Journal of Empirical Finance, 18 (5), (2011): 868-879.

LeRoy, S. Risk Aversion and the Martingale Property of Stock Returns. International Economic Review, 14, (1973): 436-446.

Lim, K.P. \& Brooks, R. The Evolution of Market Efficiency over Time: A Survey of the Empirical Literature. Journal of Economic Survey, 25(1), (2011): 69-108.

Lo, A. W. The Adaptive Markets Hypothesis: Market Efficiency from an Evolutionary Perspective. Journal of Portfolio Management, 30, (2004): 15-29.

Lo, A. W. Reconciling Efficient Markets with Behavioral Finance: the Adaptive Markets Hypothesis. Journal of Investment Consulting. 7(2), (2005): 21-44.

Lucas, R. Asset Prices in an Exchange Economy. Econometrica, 46, (1978): 1429-1446.

Mobarek, A. \& Keasey, K. Weak-form market efficiency of an emerging Market: Evidence from Dhaka Stock Market of Bangladesh., Paper presented at the ENBS Conference held in Oslo, (2000).

Neely, C. J., Weller, P. A., \& Ulrich, J. M. The Adaptive Markets Hypothesis: Evidence from the Foreign Exchange Market. Journal of Financial and Quantitative Analysis, 44(2), (2009): 467488.

Popović, S. Portfolio Analysis - Quantitative Aspects of Investing in Securities, (Podgorica: Modus Center for Statistical Research and Prognoses), (2000), 158-161.

Self, J. K. \& Mathur, I. Asymmetric Stationarity in National Stock Market Indices: An MTAR Analysis. Journal of Business, 79(6), (2006): 3153-3174.

Sullivan, R., Timmermann, A., \& White, H. Data-Snooping, Technical Trading Rule Performance and the Bootstrap. Journal of Finance. 54, (1997): 1647-1691. 
Todea, A., Ulici, M. \& Silaghi, S. Adaptive Markets Hypothesis: Evidence from Asia-Pacific Financial Markets. The Review of Finance and Banking, 01(1), (2009): 007-013.

Worthington, A. C. \& Higgs, H. Random walks and market efficiency in European equity markets. Global Journal of Finance and Economics, 1(1), (2004): 59-78. 


\title{
HIPOTEZA O ADAPTIVNOSTI TRŽIŠTA: EMPIRIJSKI DOKAZ SA TRŽIŠTA AKCIJA CRNE GORE
}

\begin{abstract}
SAŽETAK
$\mathrm{U}$ ovom radu je ispitivana hipoteza o adaptivnosti tržišta kroz analizu tri faktora za koje smo pretpostavili da imaju utjecaja na slabu formu efikasnosti tržišta: period promatranja, vremenski horizont predstavljen dužinom pokretnog prozora i razina agregiranosti podataka. Analiza je provedena na tržišno ponderiranom indeksu MONEX20 koji predstavlja proxy za crnogorsko tržište akcija u periodu od 2004-2011. godine. Metoda pokretnih prozora s fiksnim parametrima u svakom prozoru pojedinačno je primijenjena kako bi izmjerili odstupanja od hipoteze slučajnog hoda tokom vremena. Zapravo, pomoću ove analize je ispitivano variranje kratkoročne linearne ovisnosti prinosa iz prethodnog i tekućeg perioda. Metoda pokretnih prozora je primijenjena na autokorelacijski koeficijent prvog reda (AC1) i na test znakova (neparametarski test), s obzirom na to da serija podataka indeksa MONEX20 ne dolazi iz normalnog rasporeda. Analiza je dovela do zaključka da sva tri faktora utječu na razinu slabe forme efikasnosti crnogorskog tržišta akcija, što ima ozbiljne konsekvence na mogućnosti ostvarivanja profita tokom vremena na ovom tržištu.

Ključne riječi: hipoteza o adaptivnosti tržišta, slaba forma hipoteze o efikasnosti tržišta, metod pokretnih prozora, autokorelacijski koeficijent, test znakova, Crna Gora
\end{abstract}

